Review Article

\title{
Signatures of Refertilisation: Perspective from Peridotites in Ophiolite Sequences
}

\author{
SHREMA BHATTACHARYA ${ }^{1, *}$ and TITHI GHOSH ${ }^{2,3}$ \\ ${ }^{1}$ Geoscience Division, Physical Research Laboratory, Ahmedabad, India \\ ${ }^{2}$ Department of Earth and Atmospheric Sciences, University of Houston \\ ${ }^{3}$ Fugro USA Marine, Inc. Houston, TX
}

(Received on 25 July 2017; Revised on 26 November 2018; Accepted on 16 August 2019)

\begin{abstract}
Majority of the ophiolites is conceded in the geologic record, been formed either in mid ocean ridge (MOR) or in supra subduction zone (SSZ) setting. However, many of their origins are controversial. The peridotites from the mantle section of the ophiolites serve as a window to look deep into the mantle evolution and provide snapshot details on the origin of ophiolite. In this review, we have discussed four different kinds of peridotites from Josephine, Oman, Andaman ophiolites belong to various tectonic settings and abyssal peridotites from Mid ocean ridges.

In general, $\mathrm{Cr} \#, \mathrm{Mg} \#$, trace elements in clinopyroxenes of the peridotites are important indicators of different mantle processes. Variations in peridotite chemistry, their major and trace element concentrations depend on various degrees of partial melting. Refertilisation-a post melting modification event might change the trace element composition of residual peridotites based on the composition of the percolating melt. Effect of refertilisation can be well diagnosed by trace element patterns of clinopyroxenes within the peridotites because Cpx trace element pattern can be easily affected by late stage melt percolation. Comparatively dry partial melting occurs at MOR than SSZ setting during the generation of abyssal peridotites and the effect of refertilisation in these rocks is little. In each stage of dry melting (MOR setting) and/or wet flux melting (SSZ setting)event during the process of ophiolitic peridotite or abyssal peridotite formation, Cpx plays an important role as melting events leave imprints within the Cpx trace element concentrations.
\end{abstract}

Keywords: Ophiolite; Peridotite; Clinopyroxene; Andaman; Oman; Josephine; SSZ; MOR

\section{Introduction}

Ophiolites are fossilised oceanic lithosphere, primarily formed in Supra Subduction Zone (SSZ) or Mid Ocean Ridge (MOR) and/or in transitional environment (Metcalf and Shervais, 2009). They are preserved along the present-day suture zones and provide the 'snapshot' details of origin and evolution of oceanic lithosphere that otherwise been consumed by subduction and/or continental collision. Ophiolites are mainly comprised of mantle section (peridotite), mantle transition zone (i.e. MTZ composed of peridotite, pyroxenite, gabbro, troctolite etc.) and crustal section (basalt and often acid volcanics). However, these occurrences of rock types vary depending on their mode of formation. For example, in a typical SSZ setting, a series of volcanic rocks from basalt-rhyolite to boninite may present whereas, a MOR setting will lack these acidic volcanic rocks (Whattman and Stern, 2011). Nevertheless, there is no unique way to constrain between these major geodynamic environments of ophiolite formation undoubtedly. Thus, inferring the paleo-tectnoic environment from many ophiolites around the world remains debatable. However, in general, melting processes in MOR and SSZ settings are quite different. Any peridotite forms in either of these settings. Relatively dry melting of peridotite ( $\sim 5$ to $15 \%)$ takes place in MOR setting (Jean et al., 2010). On the other hand, in SSZ, during initiation of the subduction and fore arc spreading MORB like magmas generate due to decompression melting of mantle. As the subduction proceeds, continued melting of mantle results in depleted mantle 
residue (harzburgite) that has been progressively metasomatised due to continuous input of fluid $(>20 \%)$ from subducting slab and sediments (e.g., Parkinson et al., 1992; Ishii et al., 1992; Arai 1994a; Parkinson and Pearce 1998; Pearce et al., 2000; Widomet al., 2003). Melting of metasomatised mantle residue gives rise to Island Arc Basalt (IAB) and boninite like lavas, consequently. Therefore, we can use peridotite from mantle section of ophiolites to understand the contrasting melting processes in different tectonic settings in order to characterise the different geodynamic environments of ophiolite formation.

Trace element composition of clinopyroxene $(\mathrm{Cpx})$ in residual mantle peridotite from MOR (Johnson et al., 1990; Johnson and Dick, 1992; Hellebrand et al., 2002) and ophiolites (Rampone et al., 1996; Batanova et al., 1998; Suhr et al., 1998) provides valuable information on melting processes. Clinopyroxene is a common and abundant mineral throughout the ophiolite sequence and a good reservoir of many trace elements including REE. The trace elements and REE in clinopyroxene preserve the signature of chromatographic reaction of melt-rock interaction at each stage of melting. Post melting modification such as refertilisation is common especially in SSZ setting, occurring due to percolating or inefficiently extracted melt that crystallises in interstices and on grain boundaries. Abyssal peridotite typically forms in MOR setting and hence, this study attempts to review how clinopyroxene behaves in anhydrous vs. hydrous melting of mantle residual peridotites in MOR and ophiolites respectively in order to unfold the melting process and ophiolite formation in different tectonic settings.

The mantle residual peridotite from Josephine (Calidonian) and Oman (Tethyan) ophiolites are compared with the abyssal peridotites from MOR. The Josephine and Oman ophiolites have supra subduction zone and transitional origin, respectively. In light of this, we have also discussed the possible mode of formation of residual peridotite from Andaman ophiolite (possibly part of Tethyan orogeny) that shares a common age of formation of $95 \mathrm{Ma}$ (Pedersen et al., 2010;Sarma et al., 2010) with Oman ophiolite (Lippard et al., 1986; Nicolas, 1989).

\section{Geological Background}

\section{Josephine Ophiolite}

Josephine ophiolite is partly dismembered Caledonian ophiolite sequence emplaced at $157 \mathrm{Ma}$ (Saleeby et al., 1982; Dick, 1976) and located in the Kalamath Mountains in southern Oregon and northwestern California (USA). Josephine ophiolite resides in a paleo-position between two segments of rifted Jurassic arc systems. Josephine ophiolite is considered to form in an extensional back arc setting where suprasubduction zone magmas are overlain by MORB magmas. The ophiolite preserves the complete sequence of crustal and mantle section consisting of basalt, sheeted dyke, gabbro and gabbro interlayered with wehrlite, and dunite, in fault contact with peridotite tectonites. The Josephine peridotite is the base of the ophiolite followed by MTZ (Mantle Transition Zone) and crustal sections. Ophiolite sequence is conformably overlain by thin siliceous pelagic sediments followed by thick sequence of turbidites known as "Galice formation" (Harper 1984).

The Josephine peridotite presents large massif body $\left(640 \mathrm{~km}^{2}\right)$ comprised of variably depleted spinel harzburgite and lherzolite. Plagioclase is largely absent. Peridotites are partially or completely altered to serpentinites (Roux Le et al., 2014). In addition to massif peridotites, variations of pyroxene rich and pyroxene poor layers of peridotite are also present at centimetre scale. Dunite occurs as dikes, tabular bodies and large irregular podiform bodies.

\section{Oman Ophiolite}

Oman ophiolite is a part of Tethyan oceanic lithosphere that was emplaced at $(95 \mathrm{Ma})$ the Arabian continent (e.g., Lippard et al., 1986; Nicolas, 1989). There are controversies regarding the origin of Oman ophiolite whether it was formed in a mid ocean ridge (Boudier et al., 1988; Nicolas, 1989) or in a back-arc basin (Alabaster et al., 1982; Lippard et al., 1986). However, presently a combined origin is concluded where at the first stage MOR magmatism is overlain by second stage arc type magmatism at subduction zone during obduction (Arai et al., 2006).

Mantle section of Oman ophiolite is comprised of lherzolite near the base of the lower section (Lippard et al., 1986 and Takazawa et al, 2003). 
Harzburgite with both high and low Cr\# spinel is present (e.g., LeMe'e et al., 2004; Arai et al., 2006; Monnier et al., 2006; Tamura and Arai, 2006). Dunite, wehrlite and gabbro are closely associated with harzburgite. The thickness of MTZ varies from $\mathrm{m}$-scale to over $500 \mathrm{~m}$ where dunite is the major phase and wehrlite is subordinate (Koga et al., 2001; Boudier and Nicolas, 1995). Gabbro sills are frequently present in MTZ. Dunite and wehrlite are found as later intrusive into the crustal section (Benn et al., 1988).

\section{Andaman Ophiolite}

Andaman Ophiolite occurs on the Andaman accretionary prism of the Indian-Eurasian convergent plate boundary. The age of the Andaman ophiolite complex is $95 \pm 2 \mathrm{Ma}$ based on U-Pb geochronology of zircon from plagiogranites (Pedersen et al., 2010; Sarma et al., 2010). The origin of Andaman Ophiolite remains controversial. Several authors suggested that ophiolite was formed in a transitional geodynamic setting from Mid Oceanic Ridge (MOR) to arc environment (SSZ), where MORB mantle accreted to mantle wedge under subduction zone influence (Pal et al., 2011; Ghosh et al., 2013, 2014). Other studies suggested a shallow magma chamber origin, possibly beneath a slow spreading ridge (Ray et al., 1988; Srivastava et al., 2004).

In Andaman Islands, preserved ophiolite sequences show marked mineralogical and geochemical differences from north to south, especially in terms of their mantle sequence (Ghosh et al., 2013). The mantle peridotites in middle/ north Andaman Island mostly show lherzolitic affinity and rarely grade into clinopyroxene-bearing harzburgite (Ghosh et al., 2013). In contrasts, peridotites in the Rutland Island show harzburgitic nature (Ghosh et al., 2014). In Rutland Island the lithological assemblage represents Mantle Transition Zone (MTZ) sequence (Ghosh et al., 2014) composed of wehrlite, olivine rich troctolite, pyroxenite and gabbroic rocks.

\section{Abyssal Residual Peridotite}

Abyssal (i.e. seafloor) peridotite represents the lithospheric mantle composition (Salters and Stracke, 2004; Workman and Hart, 2005) exposed by thrusting on the seafloor at mid ocean ridges or transform faults. They have wide variation in composition which reflects mantle heterogeneity. They are mainly grouped into residual peridotite and veined peridotite. Peridotites without any interstitial plagioclase or cross cutting vein are classified as residual peridotite. Because, both the plagioclase and cross cutting veins are considered as evidence of melt addition (Warren, 2016). Due to least effect of melt-rock interaction, residual peridotite is widely studied as upper mantle representative following melt extraction.

Here, we compare the global residual peridotite from different MOR setting reported in Warren, (2016) with the peridotites from aforesaid ophiolites.

\section{Petrographic Characteristics}

As discussed in section 2, the mantle section of most of the ophiolites contains wehrlite, harzburgite, lherzolite and dunite as primary rocks. Dunite and harzburgite are in general more depleted compared to lherzolite in terms of elemental concentration. Harzburgiteis residual phase formed by melting of lherzolite and dunite is replacive in origin. Thin section studies of these rocks from the mantle section of the ophiolites reveal the melting and melt-percolation history. Though, in most of the scenarios, the rocks are variably altered, only partially preserved primary phases give an idea of the initial composition. In general, the peridotites from Josephine, Oman and Andaman have olivine, spinel, orthopyroxene (Opx), clinopyroxene (Cpx) and sometimes plagioclase as primary phases. At places, Cpx has given way to amphibole (tremolite) as an alteration product. Before going into the petrographic details of peridotites, it is noteworthy to mention that the rocks experiencing higher degree of partial melting have less primary $\mathrm{Cpx}$ compared to the rocks with lower degree of melting; because during fractional metilng, $\mathrm{Cpx}$ is one of a few first phases that goes into the melt. On the other hand, the occurrence of spinel and Cpx in interstices and on grain boundaries are believed to be a product of late stage melt percolation or metasomatism.

\section{Josephine Ophiolite}

In the lower peridotite section of Josephine ophiolite, lherzolites and harzburgites are the abundant ones. Occasionally, dunite is present in various forms e.g. podiform, lenses etc. According to Roux Le et al. (2014) the mantle section is devoid of plagioclase and contains less than 5\% Cpx. The degree of serpentinisation is predominantly less than $40 \%$ for 
majority of the samples but it is higher at the base of the ophiolite. Lherzolite and harzburgite both show different kind of textures- mylonitic texture formed due to high temperature deformation and protogranular texture developed as a result of solid peridotite residue which has experienced partial melting. On average, the Cpx content of the peridotites are around $5 \%$, but lherzolites have around $13 \%$ of $\mathrm{Cpx}$ in it. Irregular shape of the grains and undulose extinction present in Opx, Cpx, and olivine minerals of harzburgite indicate that the rocks have undergone deformation at high temperature. The $\mathrm{Cpx}$ grains are mostly smaller in size than Opx. Spinels in lherzolites are present in the interstitial spaces around the pyroxenes and might indicate incongruent melting of pyroxene. The olivine and Opx are altered to serpentine at few places, but degree of alteration is more prominent in Opx compared to olivine which indicates the alteration temperature to be more than $300^{\circ} \mathrm{C}$ because at this temperature Opx is more susceptible to transformation compared to olivine.

\section{Oman Ophiolite}

The petrography of mantle rocks from north, central and southern part of Oman ophiolite partially varies. The presence of basal lherzolites is reported from the northern and central part whereas, $\mathrm{Cpx}$ bearing harzburgites are found from southern Oman ophiolite (Takazawa et al, 2003; Khedr et al., 2014). The mantle section of central Oman ophiolite is mainly composed of lherzolite at the base and harzburgite with sporadic presence of dunite (Boudier \& Nicolas, 1995). Two types of basal lherzolites were observed in the central part of Oman- one is massive with mylonitic structure (Type I) and the other (Type II) is foliated (Khedr et al., 2014). The effect of serpentinisation is more on type II lherzolites compared to type I. The mantle section is occasionally intruded by cross-cutting pyroxenite dykes (Takazawa et al., 2003). In general, these peridotites contain 0.514 vol\% Cpx. Presence of Cpx in northern ophiolite is infrequent and they occur as narrow bands within harzburgites. The lherzolites from northern Oman don't contain any plagioclase and spinel exist as interstitial grains similar to Josephine ophiolite. The Cpx is altered to hornblende at places in the lherzolites of central Oman ophiolite but within harzburgites, alteration has no effect on Cpx (Khedr et al., 2014). Sometimes, lamellae of Opx can be found within large Cpx grains and patchy appearance of Cpx is noticed within lherzolites. The harzburgites from central Oman preserve the primary texture of the grains having equigranular olivine surrounded by pyroxenes instead of week serpentinisation. On the other hand, harzburgites from northern Oman has experienced higher degree of serpentinisation and contain $\mathrm{Cpx}$ occasionally (Takazawa et al, 2003).

\section{Andaman Ophiolite}

The Andaman ophiolite consists of a deformed, residual mantle section with a thickness of more than 700 meter in north Andaman (Ghosh et al., 2014). This section contains highly serpentinized peridotites (Pal, 2011) and large chromite pods. The mantle section consists mainly of lherzolite, dunite and Cpx-bearing harzburgite. The composition of south Andaman ophiolite consists of mainly depleted harzburgites and Cpx bearing harzburgites, but the middle and north Andaman with: ophiolite comprise of lherzolite (Ghosh et al., 2013). Wehrlites can be found in the transition zone of the south Andaman ophiolite. Majority of the mantle rocks have experienced different degrees of serpentinisation ranging from $50-80 \mathrm{vol} \%$ in the Andaman Ophiolite (Pal, 2011). A considerable part of the rocks is coarse grained, showing interlocking texture. The grains present in these mantle rocks are often brecciated and the presence of serpentinite veins form a mesh texture (Pal, 2011). In middle and north Andaman, the spinels within mantle section and residual peridotites, are found in two forms- massive pods of chromite within mantle section and as accessory grain in the residual peridotites (Ghosh et al., 2013), and also show signs of mantle deformation. The residual spinel grains are embedded within serpentine matrix (Ghosh et al., 2013) and show resorbed margins with occasional euhedral grains ( $\mathrm{Pal}$, 2011). Within less depleted lherzolites at middle and north Andaman, olivine forms dunite pods and at places, olivine is replacing Opx forming embayed boundary of the relict pyroxene grain (Ghosh et al., 2013). But the occurrence of podiform dunite is much less compared to Oman ophiolite. Symplectite texture (intergrowth formed due to recrystallization of unstable phases) of spinel and Cpx can be seen within Opx of lherzolites and are believed to be formed from garnet. Although, this symplectite texture is more developed in north Andaman, it can be observed at other parts of the Andaman ophiolite too. Presence 
of exsolved lamellae of Cpx within Opx has been also observed. Wherlites in the south Andaman ophiolite transition zones contain less than $40 \%$ modal Cpx (Ghosh et al., 2014).

\section{Abyssal Peridotite}

The residual abyssal peridotite has experienced various degrees of alteration and depending on that, they have preserved mineral phases. Among the mineral phases, spinel is the most preserved one and olivine is the most altered one. While considering the rock types, dunites seem to be affected by alteration to a greater extent compared to others and only $3 \%$ of dunites contain Cpx (Warren, 2016). The harzburgites are the most abundant rock type within the abyssal peridotites globally and they contain less than 5 vol\% Cpx. Garnet is normally not being found in the abyssal peridotites and the high temperature amphiboles are rare too (Warren, 2016). Low temperature amphiboles can be found as an alteration product.

\section{Major Element Characteristics}

Before going into the details of the major element chemistry of mantle rocks, it is noteworthy to mention some important parameters for better understanding of the major element chemistry. The $\mathrm{Cr} \#((\mathrm{Cr} /$ $(\mathrm{Cr}+\mathrm{Al}))$ atomic ratio) of spinel is an important indicator of degree of partial melting in the mantle (Dick \& Bullen, 1984). Cr being the compatible element in spinel structure, partial melting results in enrichment of $\mathrm{Cr}$ in the residual peridotite by raising the $\mathrm{Cr} \#$. On the other hand, Ti is very incompatible during mantle melting and goes into the melt. Thus, progressive partial melting of the mantle removes $\mathrm{Ti}$ from the solid and the residue becomes depleted with respect to Ti. Fo (forsterite) content or $\mathrm{Mg \#}(\mathrm{Mg} /$ $(\mathrm{Mg}+\mathrm{Fe})$ atomic ratio) of olivine is another useful parameter to constrain the degree of partial melting. Higher degree of partial melting generally increases the Fo content or $\mathrm{Mg} \#$ of the rock.

\section{Josephine Ophiolite}

The Fo content of olivine of the peridotites varies from 90-91.9 comparable with the abyssal peridotite values estimated from spinel peridotites from slow spreading ridges. According to Roux Le et al. (2014) the Cr\# of spinels shows a range from 16-69.5 and that exceeds the $\mathrm{Cr} \#$ range of abyssal peridotite. $\mathrm{The}^{\mathrm{TiO}}{ }_{2}$ content of the spinels are low and ranges from 0.010.13 . The pyroxenes present in the rocks are mainly diopside and enstatite. The $\mathrm{Al}_{2} \mathrm{O}_{3}$ content of these pyroxenes show a broad range from $1.1-5.3 \mathrm{wt} \%$ and the $\mathrm{Mg} \#$ varied from 90.2-93.9 which is quite high. The $\mathrm{TiO}_{2}$ content of $\mathrm{Cpx}$ rich harzburgites and lherzolites are higher than the residual harzburgite. In the OSMA (olivine-spinel mantle array) plot (Fig. 1), most of the Josephine samples (Harzburgite) lie in the forearc peridotite field. There are a few lherzolites plot in the abyssal peridotite field (Fig. 1), showing less amount of partial melting. While the data from

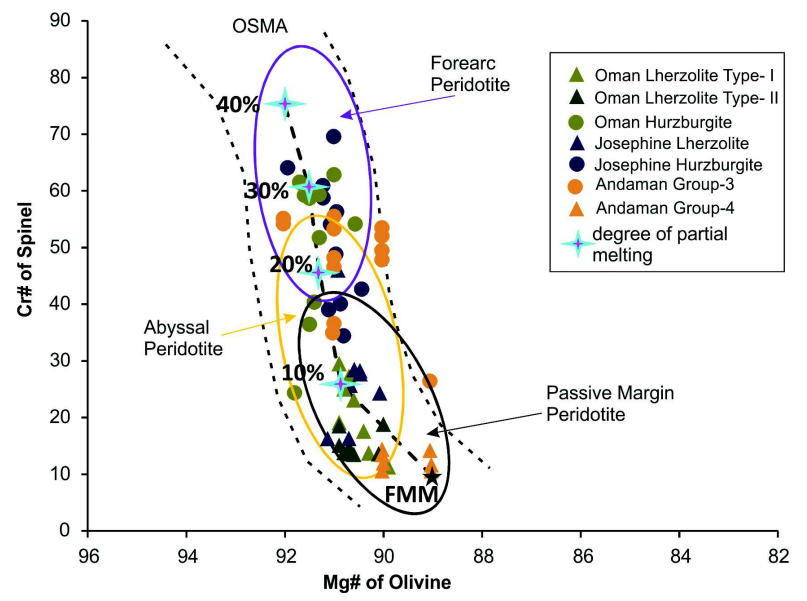

Fig. 1: Compositional relationship between Fo content of olivine and $\mathrm{Cr} \#$ of coexisting spinel of peridotites from the Josephine, Oman, Andaman Ophiolite on olivine-spinel mantlearray (OSMA) plot of Arai, 1994b. Data sources are from Roux Le (2014), Khedr et al. (2014), Takazawa et al. (2003) and Ghosh et al. (2013)

this rock are plotted on the $\mathrm{TiO}_{2} \mathrm{wt} \%$ in $\mathrm{Cpx}$ vs. $\mathrm{TiO}_{2}$ whole rock, they show a nice correlation. There is a considerable amount of $\mathrm{TiO}_{2}$ in $\mathrm{Cpx}$ but the whole rock $\mathrm{TiO}_{2}$ concentration is low.

\section{Oman Ophiolite}

The Fo content of olivines from lherzolites in the northern Oman ophiolite varies from 90-92 indicating higher degree of partial melting whereas, the $\mathrm{Cr} \#$ of spinel lies between 0.1-0.6, having the lower value of Cr\# at the base (Takazawa et al., 2003). These values overlap with the abyssal peridotites. Although, for most of the elements in lherzolites (northern Oman), the ranges are comparable to those of the abyssal 
peridotites. The Na content of $\mathrm{Cpx}$ in some of the lherzolites is higher than the abyssal peridotites and is present at the areas being affected by hydrothermal alteration or melt-rock interaction (Takazawa et al., 2003). The $\mathrm{TiO}_{2}$ content of the Cpx doesn't change much from sample to sample. The Mg\# of olivine from the lherzolites of central Oman ophiolite ranges (90-92) and they show an enrichment in $\mathrm{Al}_{2} \mathrm{O}_{3}$ (1.9$3.12 \mathrm{wt} \%)$. The harzburgites in this area are more depleted in $\mathrm{Ti}, \mathrm{Na}, \mathrm{Ca}$ content compared to the lherzolites (Khedr et al., 2014). Major element trend of the peridotites from central Oman matches with the abyssal peridotite trend from the Indian and Pacific mid ocean ridges (Tazakawa et al., 2003; Niu, 2004). In the OSMAplot (Fig. 1) for Cr\# of spinel vs. Mg\# of olivine, Oman harzburgites mainly occupy the forearc peridotite field whereas, the lherzolites fall in the abyssal peridotite field. The spread of $\mathrm{Mg} \#$ of olivine is tight for the Oman samples in Fig. 1. Further, the Oman harzburgite and lherzolite form two different clusters in the $\mathrm{TiO}_{2} \mathrm{wt} \%$ in $\mathrm{Cpx}$ vs. $\mathrm{TiO}_{2}$ whole rock. The Oman lherzolite shows wider spread in the $\mathrm{TiO}_{2}$ content and are enriched in $\mathrm{TiO}_{2}$ compared to Oman harzburgite.

\section{Andaman Ophiolite}

The chromites from mantle peridotite and dunites have high $\mathrm{Al}$ content of 32-49.6 wt \% (Pal, 2011). Two types of podiform chromites were identified based on their $\mathrm{Cr}_{2} \mathrm{O}_{3}$ content: one with high $\mathrm{Cr}_{2} \mathrm{O}_{3}$ content of 54$60 \%$ and the other with low $\mathrm{Cr}_{2} \mathrm{O}_{3}$ content of 39$42 \%$ (Ghosh et al., 2013). Additionally, the chromian spinels were characterized into four distinct groups on the basis of their Cr\#. The group 1 consists of podiform spinels from Rutland (south Andaman) with high Cr\# (0.7) whereas the group 2 is from north Andaman podiform chromites containing a range of $\mathrm{Cr} \#$ from 0.48 to 0.79 . Group 3 has the residual spinels from Rutland with medium Cr\# from 0.37 to 0.55 and group 4 consists of residual spinel grain from middle and north Andaman having a lower Cr\# (0.09-0.23). All these four groups of spinels have different chrome $\mathrm{Mg} \#$ as well, ranging from 0.41 to 0.81 (Ghosh et al., 2013). The $\mathrm{TiO}_{2}$ content of group 1 and group 2 spinels $(0-0.5 \mathrm{wt} \%)$ are higher than group 3 and $4(0-0.25$ $\mathrm{wt} \%$ ). The Mg\# of olivines from middle and north Andaman varies from 0.71 to 0.81 . The wherlites form south Andaman contain olivines with high Fo mole $\%$ of 90 and low $\mathrm{NiO}(\leq 0.2 \mathrm{wt} \%)$ and $\mathrm{CaO}$ $(\leq 0.05 \mathrm{wt} \%)$ content (Ghosh et al., 2014). Cr\# vs.Mg\# for all the samples from group-1 to Group-4 are shown in Ghosh et al. (2014). Herein Fig. 1, we have only considered plotting peridotite samples from Rutland (group-3) and North Andaman (group-4). The datashows large variation in $\mathrm{Cr} \#$. The data plots into two separate regions, one within the area of passive margin peridotite and the other shows a mixed signature of abyssal and some influence of forearc peridotite.

\section{Abyssal Peridotites}

A range of $\mathrm{Cr} \#$ exists for the abyssal peridotites but they don't exceed 60 and varies form 10-60 in residual peridotites (Fig. 1 and Fig. 5 in Warren, 2016). Generally, the Cr\# in lherzolite is quite low and has a limit of 30 whereas the harzburgite covers the whole $\mathrm{Cr} \#$ range mentioned above. The $\mathrm{TiO}_{2}$ concentration normally do not cross $5 \mathrm{wt} \%$.

\section{Characteristics of REE and Trace Elements Composition of Clinopyroxene}

\section{Josephine Ophiolite}

Clinopyroxenes are generally enriched in HREE (Heavy Rare Earth Element) and depleted in LREE (Light Rare Earth Element) in Josephine peridotites. HREE concentrations of clinopyroxene in Cpx rich Harzburgite/Lherzolite is 6-7 times higher than chondritic values whereas harzburgites are $<2$ times lower than the chondritic values (Fig. 2A). Harzburgite have variable LREE concentrations however, $\mathrm{Cpx}$ rich Harzburgite/Lherzolite and harzburgite have similarly low LREE concentrations. This study observed that the lherzolites are LILE (Large Ion Lithophile Element) enriched and some of the HFSE element like $\mathrm{Zr}$ is depleted and a sharp $\mathrm{Nb}$ peak is observed (Fig. 2B). The Cpxs in harzburgites are overall depleted in trace element concentrations showing LILE enriched and depleted HFSE patterns (Fig. 2B).

\section{Oman Ophiolite}

REE and trace element patterns of Cpx are plotted from Type I and Type II lherzolite, harzburgite from central Oman (Wadi Sarami, Khedr et al., 2014) and northern Oman (Fizh block, Takazawa et al., 2003) ophiolite (Fig. 2).

REE content of Cpx in Oman lherzolite varies 


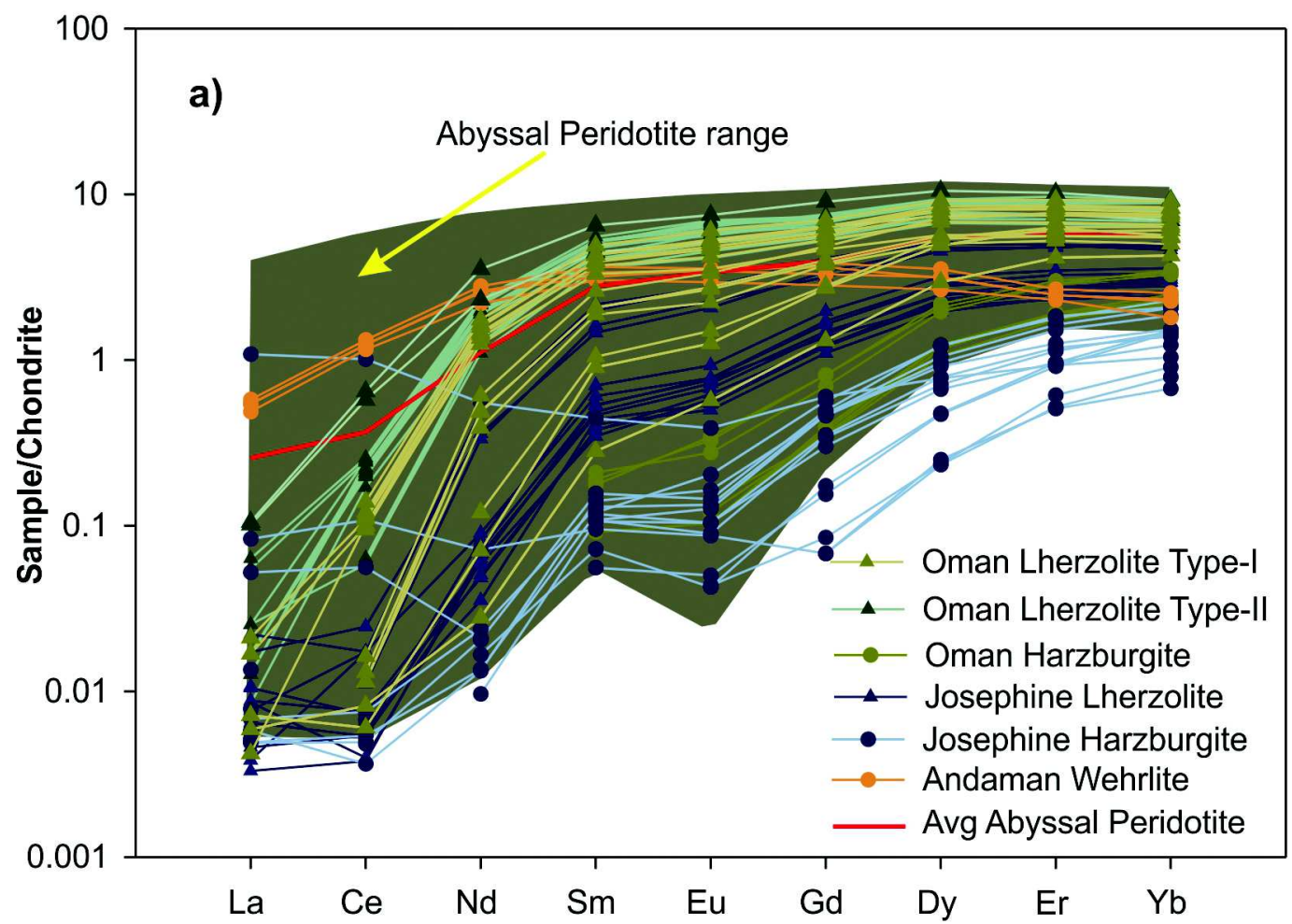

Fig. 2A: Rare Earth Element patterns of clinopyroxene normalised to chondrite (Sun and Mc Donough, 1989) from Josephine, Oman, Andaman and abyssal peridotites

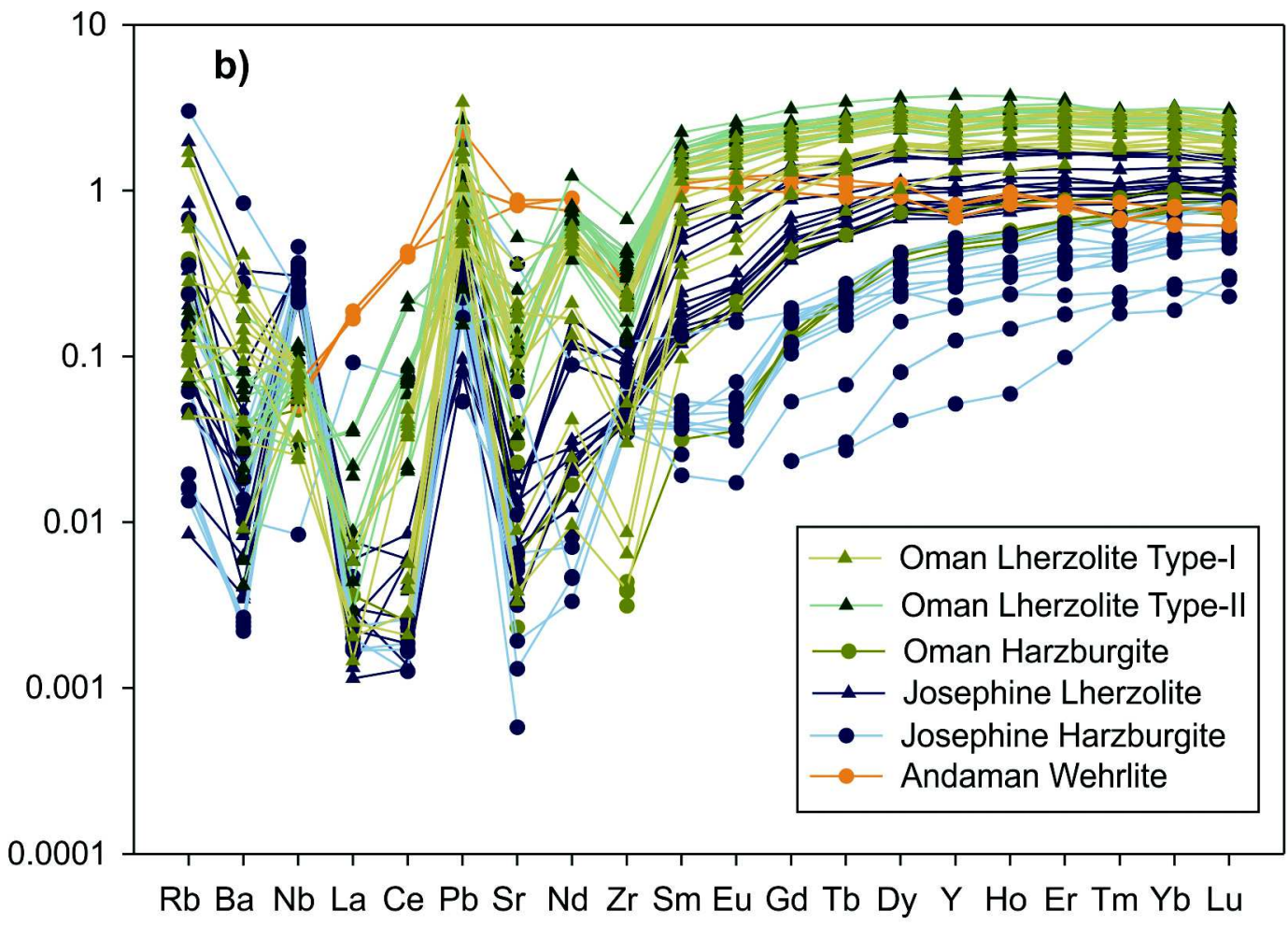

Fig. 2B: Multi Element patterns of clinopyroxene from peridotitic rocks normalised to primitive mantle (Mc Donough et al., 1992) from Josephine, Oman, Andaman ophiolite. Data sources of figure 2 are from Roux Le (2014), Khedr et al. (2014), Takazawa et al. (2003), Ghosh et al. (2014) and Warren (2016 and references therein) 
from $\sim 5$ to 10 times above chondrite. Both Type I and Type II lherzolite from central Oman ophiolite show similar LREE/HREE ratio $\left[(\mathrm{Ce} / \mathrm{Yb})_{\mathrm{n}}=0.007\right.$ to 0.028] in Cpx where LREE is strongly depleted and HREE is enriched (Fig. 2A). Only MREE is slightly higher in Cpx of Type I lherzolite than HREE. Type I lherzolite from northern Oman ophiolite shows flat to spoon shaped REE patterns with slight inflection in La and Ce (Fig. 2A of this study and also see Takazawa et al, 2003, Fig. 13). This is a typical indication of depleted melt percolation (e.g. Verniéres et al., 1997). REE concentrations and patterns of Type II lherzolites from northern Oman ophiolite are very similar to Type II lherzolites of central Oman ophiolite and abyssal peridotites from normal ridge segment (Fig. 2A).

REE contents of Cpx harzburgites from both Central Oman and northern Oman ophiolite have lower concentrations compare to lherzolites. However, their REE patterns are similar to lherzolites with strong depletion in LREE ( $\mathrm{La}, \mathrm{Ce}$ undetectable) and enrichment in HREE.

Trace element patterns of Cpx in both Type-I and II lherzolite and harzburgite from central and northern Oman ophiolites show similar trend (Fig. 2B). They are enriched in fluid mobile elements (e.g. Rb, $\mathrm{BaPb}$ ) and depleted in HFSE ( $\mathrm{Zr}, \mathrm{Hf}, \mathrm{Nb}$ ). However, this study observes that the Type I lherzolite from central Oman ophiolite is relatively more enriched than rest of the lherzolites of other study areas. Trace element abundances of Type-II lherzolites from both central and northern Oman are very similar. Harzburgites show lower abundance of trace elements.

\section{Andaman Ophiolite}

REE patterns of Cpx from olivine rich troctolite, wehrlite, gabbro and clinopyroxenite are so far only reported by Ghosh et al. (2014). But here we mainly focus on peridotite, i.e. wehrlite (Fig. 2A). Clinopyroxene has low REE abundance with slightly LREE depleted and relatively flat to depleted HREE pattern. The HREE depletion may suggest that the melting took place in presence of garnet. CPxs in wehrlite are LILE enriched (Fig. 2B) and they have Eu negative and $\mathrm{Sr}$ positive anomalies. That signifies early crystallisation of $\mathrm{Cpx}$ than plagioclase from a trapped melt and in addition possibly the first crystallising mineral from melt (Ghosh et al., 2014).

\section{Abyssal Peridotite}

Globally, REE concentrations of residual peridotites show a wide range from quite high-close to model DM source to very low (Fig. 2). Trace element data are sparse from abyssal peridotite mostly due to their low concentration. Lherzolite shows consistent pattern and restricted range of REE concentrations. Harzburgites show wider range of composition starting from the similar composition of lherzolites to very low concentrations. Harzburgites mainly from EPR (East Pacific Rise) are refractory. Those are cross cut by gabbro veins and show negative Eu anomalies (Dick and Natland, 1996) implying plagioclase crystallisation.

\section{Are SSZ Peridotites Melting Residues?}

However, Oman peridotites formed in transitional/mix environment and Josephine peridotites formed in SSZ but in both cases partial signature of MOR overlap with SSZ. This is because, in case of SSZ environment first expression of magma formation is MORB like due to initial extension before initiation of subduction. The Cr\# in spinel increases from lherzolite to harzburgite. In Central Oman Cr\# in spinel increases from Type-II to Type-I lherzolite to harzburgite although, there is no significant difference observed in $\mathrm{Cr} \#$ in spinel in both types of lherzolites. In northern Oman, the Cr\# in spinel is similar in Type-I and type II lherzolite but later is somewhat lower in range (Fig. 1). Josephine and Andaman peridotites follow the similar trend. Roux Le et al. (2014, in Fig. 4a) shows that $\mathrm{Cr} \#$ in spinel steadily increases with decreasing abundance of clinopyroxene in case of Josephine peridotite.

Residual peridotites with high $\mathrm{Mg} \#$ in olivine along with higher $\mathrm{Cr} \#$ in spinel indicate a significant amount of partial melting. As the $\mathrm{Cr} \#$ of spinel remains mostly unaffected by percolating melt or fractional melting events, it is a good indicator of melting residues. Partial melting preferentially removes $\mathrm{Al}$ and $\mathrm{Ti}$ from spinel, but Cr get enriched over time as it remains in the solid during melting. So, higher $\mathrm{Cr} \#$ suggests that the rock has experienced high degree of partial melting. As discussed in the major element chemistry section (or section number), all of the three ophiolites 
(Oman, Josephine, Andaman) have higher Cr\#. Different $\mathrm{Cr} \#$ indicates different degrees of partial melting. On the other hand, $\mathrm{Mg \#}$ of olivine also increases with increasing partial melting, but this cannot be used alone as a probe. Further, in the OSMA plot (Fig. 1) majority of the Josephine samples and Oman harzburgites fall in the forearc peridotite field which has experienced at least $18 \%$ of partial melting. Without the input of water, this high amount of partial melting is not possible. The abyssal peridotites (adiabatic melting) experience partial melting ranging from less than $10 \%$ to $20 \%$ and the Cr\# is less than 6. At the subduction zones, the peridotites experience higher degree of melting because of continuous flux of water. Therefore, the peridotites from three different localities with low $\mathrm{Al}$ and $\mathrm{Ti}$ with high $\mathrm{Cr}$ content in spinel indicate melting residues.

\section{Refertilisation and Late Stage Metasomatism}

Refertilisation is one of the post melting modifications occurs due to percolating or inefficiently extracted melt that crystallises in interstices and on grain boundaries. Here, we discuss the overall signature and effect of post melting modifications of the aforesaid ophiolites.

Josephine ophiolite has an established suprasubduction zone origin. Therefore, Josephine ophiolite provides direct understanding on the nature of melting and post melting effects that might occur in case of SSZ ophiolites. According to Roux Le et al. (2014) field data can reveal a lot about melting condition especially in case of Josephine Ophiolite. Melting of mantle can occur either by increasing temperature or by addition of water. In the former case, variation in degree of melting $(\sim 15 \%)$ could occur due to higher temperature $\left(150^{\circ} \mathrm{C}\right)$, in turn gives rise to large scale transitional outcrop between the fertile and depleted peridotite. On the other hand, if water is responsible for the melting of mantle, the solidus temperature of the mantle wedge decreases and facilitates partial melting that in turn leads to small scale lithological variations. However, experimental studies show that little amount of water is also able to produce different degree of melting of peridotite (Kelemen et al., 2003, Gaetani and Grove, 1998 etc). Both small and largescale lithological variations are present in Josephine peridotites. The large-scale variations are attributed to the presence of water. Several authors (e.g.
Rampone et al., 1997; Muntener et al., 2004; Le Roux Le et al., 2007) suggested that the refertilisation caused the sharp lithological variations. Roux Le et al. (2014) suggested that in addition to refertilisation melt flux is also a probable reason for these sharp metre scale lithological variations in peridotite. Figure 3 shows that clinopyroxenes from Josephine harzburgite plot in the field of supra-subduction zone suggesting a high degree of melting under hydrous condition. However, their quantitative melting models suggest that Josephine peridotite cannot be produced solely by hydrous melting unless otherwise the mantle wedge is replenished by fluids during melting, i.e. flux melting. Therefore, variable degree of flux melting can produce the depleted harzburgite to $\mathrm{Cpx}$ rich harzburgite and lherzolite rocks. According to the authors, the harzburgites with depleted REE requires $20-23 \%$ flux melting. They have also suggested by using models that a small percentage of boninitic melt $(<1 \%)$ refertilised the depleted harzburgites leading to the enrichmentof the LREE in Cpx.

Oman ophiolite has combined/transitional origin. Central Oman ophiolite is similar to MORB type representing a fragment of Tethyan oceanic mantle, which was detached along the oceanic fracture zones and exposed along transform or detachment faults (Khedr et al., 2014). The study shows convex upward REE patterns of Cpx from central Oman peridotites show depleted LREE (Fig. 2A) very similar to abyssal peridotite. $\mathrm{Yb}$, Dy, Ti and $\mathrm{Cr}$ concentrations also confirm their residual origin similar to abyssal peridotites (Johnson et el., 1990; Johnson and Dick, 1992; Hellebrand et al., 2001, 2002 etc). Enrichment of fluid mobile LILE compare to HFSE and LREE in Cpx (Fig. 2B), absence of textural evidence of melt percolation (presence of interstitial $\mathrm{Cpx}$ ) suggesting no effect of melt refertilisation. Opx also behaves in similar fashion to Cpx. Melt modelling also confirms no effect of refertilisation in these rocks. Based on the line of evidence, Khedr et al. (2014) suggested two melting series and sources for the generation of Type-I and II lherzolite because they have overlapping characters in degree of partial melting, chemistry of pyroxene (Figs. 2 and 3), spinel and olivine (Fig. 1). They have inferred that the Type-I lherzolite which is closely similar to abyssal peridotite in nature were formed at the base of oceanic lithosphere during Neotethyan exapansion. In contrast, Type-II lherzolite are thought to be a remnant asthenospheric material 


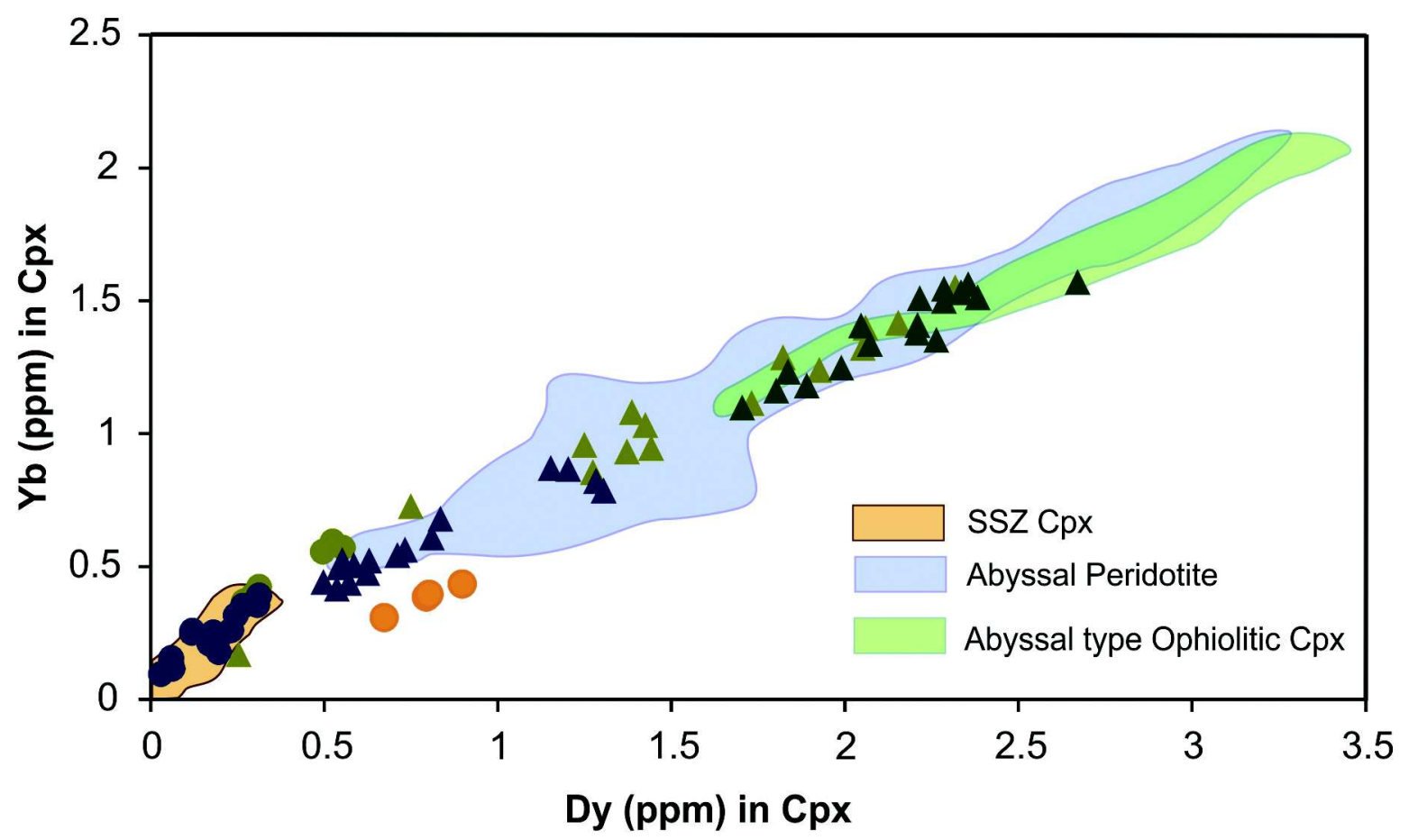

Fig. 3: Dy-Yb (ppm) concentrations in clinopyroxene from Josephine, Oman, Andaman peridotites. The fields are compiled by Jean et al. (2010) from their data and from references therein. Data sources are compiled from Roux Le (2014), Khedr et al. (2014), Takazawa et al. (2003), Ghosh et al. (2014)

trapped by the base of oceanic lithosphere during detachment and obduction. HREE in Cpx and spinel composition suggests 3-10\% melting of Type-I lherzolite, $1-5 \%$ melting of Type-II lherzolite and 15\% melting for harzburgites using near fractional melting model and Fig. 1. However, the peridotites are not affected by refertilisation; post melting metasomatic effects are observed resulting in the replacement of Cpx by hornblende and enrichment of LILE.

On the other hand, northern Oman ophiolite (Fizh Block) may have formed under SSZ setting (Arai et al., 2006; Tamura and Arai, 2006) during intraoceanic collapse and closing of a sea floor spreading ridge (Dilek et al., 2008). The weakly spoon shaped REE pattern of Cpx (Fig. 2a) and structurally close to a falling ridge system (Nicolas et al., 2000) could result refertilisation of lithospheric mantle by MORB melts in northern Oman ophiolite. The clinopyroxenes are highly depleted in incompatible elements and slight enrichment of whole rock REE with a slope from HREE to LREE in Type-I lherzolite resulted due to $12-18 \%$ melt extractions from a little garnet bearing source (Takazawa et al, 2003). According to Takazawa et al, (2003) this slight LREE enrichment attributed to the interaction of LREE enriched melt/ fluid with residues at low melt/rock ratio. In contrast, incompatible elements in whole rock (not shown) and in Cpx are higher in abundance in Type-II than TypeI lherzolite. The high $\mathrm{Na}_{2} \mathrm{O}$ content of the $\mathrm{Cpx}$ and rock, LREE depleted and flat MREE and HREE whole rock patterns suggested that the Type-II lherzolite formed by mixing where residual peridotite (Type-I) was refertilised by LREE depleted melt, generated by $10-12 \%$ incremental melting of a fertile source.

Chromianspinels from Andaman peridotites reveal a SSZ (?) history (Ghosh et al., 2013). Peridotites from Rutland (Fig. 1) to south Andaman (Ghosh et al., 2013) are typically of forearc type representing a SSZ setting. In contrast, peridotites from middle and north Andaman are similar to abyssal peridotites (Fig. 1). The composition of coexisting pyroxenes and spinels represent a nearly continuous depletion trend from north to south suggesting that the peridotite at south Andaman suffered a higher degree of partial melting than peridotites at north Andaman. Wehrlites mentioned above are from a mantle transition zone. In Fig. 3, they are slightly out of the $\mathrm{Dy}-\mathrm{Yb}$ array, however very close to abyssal 
Table 1: Comparing charateristics of three different ophiolites

\begin{tabular}{|c|c|c|c|}
\hline Characteristics & Josephine & Oman & Andaman \\
\hline Age & $157 \mathrm{Ma}$ & $95 \mathrm{Ma}$ & $95 \pm 2 \mathrm{Ma}$ \\
\hline Formation & Supra-subduction zone & $\begin{array}{l}\text { Supra-subduction and MOR } \\
\text { (Transitional) }\end{array}$ & Supra-subduction zone (?) \\
\hline Lithology & $\begin{array}{l}\text { Harzburgite \& lherzolites are } \\
\text { abundant, less dunite; No } \\
\text { plagioclase; less than } 5 \% \text { cpx in } \\
\text { most of the peridotites; interstitial } \\
\text { spinel }\end{array}$ & $\begin{array}{l}\text { Lherzolite and Harzburgite with } \\
\text { sporadic dunite; } 0.5-14 \text { vol\% } \mathrm{Cpx} \text { in } \\
\text { peridotites; interstitial spinel; no } \\
\text { plagioclase reported }\end{array}$ & $\begin{array}{l}\text { Abundant lherzolite, harzburgite, } \\
\text { dunite with occasional presence of } \\
\text { wherlite and chromite pods; less } \\
\text { than } 40 \% \text { modal Cpx in wherlites }\end{array}$ \\
\hline Deformation & $\begin{array}{l}\text { Presence of mylonite in lherzolite; } \\
\text { undulose extinction in opx, cpx } \\
\text { and olivine }\end{array}$ & $\begin{array}{l}\text { Presence of mylonites and foliation } \\
\text { within lherzolites }\end{array}$ & Grains in the rocks are often brecciated \\
\hline $\begin{array}{l}\text { Degree of } \\
\text { serpentinization }\end{array}$ & Less than $40 \%$ & $\begin{array}{l}\text { serpentinization increases from south } \\
\text { to north from being week (MOR) to } \\
\text { highly serpentinized (SSZ) }\end{array}$ & $50-80 \mathrm{vol}^{\%} \mathrm{o}$ \\
\hline $\begin{array}{l}\text { Fo content of } \\
\text { Olivines }\end{array}$ & $90-91.9$ & $90-92$ & $0.71-0.81$ \\
\hline $\mathrm{Cr} \#$ of spinels & $0.16-0.69$ & $0.1-0.6$ & $\begin{array}{l}\text { Four different groups havening } \mathrm{Cr} \# \text { from } \\
0.09-0.79\end{array}$ \\
\hline Ti content & $\begin{array}{l}0.01-0.3 \text { in spinels; } \mathrm{TiO}_{2} \text { content } \\
\text { of Cpx harzburgites and lherzolites } \\
\text { are higher than residual harzburgite; } \\
\text { bulk rock } \mathrm{TiO}_{2} \text { content is less than } \\
\text { what present within pyroxenes }\end{array}$ & $\begin{array}{l}\text { The lherzolites and harzburgites have } \\
\text { very different } \mathrm{TiO}_{2} \text { content }\end{array}$ & $0-0.5 \mathrm{wt} \%$ \\
\hline Mixed signature? & $\begin{array}{l}\text { The harzburgites plot in the } \\
\text { forearc peridotite region whereas } \\
\text { the lherzolites plot in the abyssal } \\
\text { perodotite region (Fig. 1) }\end{array}$ & $\begin{array}{l}\text { The harzburgites plot in the forearc } \\
\text { peridotite region whereas the lherzo- } \\
\text { lites plot in the abyssal perodotite } \\
\text { region (Fig. 1) }\end{array}$ & $\begin{array}{l}\text { Majority of the peridotites plot both } \\
\text { in the abyssal and forearc field (Fig. 1) } \\
\text { But the data are mainly obtained } \\
\text { from Wherlite }\end{array}$ \\
\hline $\begin{array}{l}\text { Trace element } \\
\text { of } \mathrm{CPx}\end{array}$ & $\begin{array}{l}\text { CPx in lherzolites are LILE, HREE } \\
\text { enriched and depleted in HFSE like } \\
\mathrm{Zr} \text { and LREE whereas,CPx in harz- } \\
\text { burgites are overall depleted in trace } \\
\text { element concentrations with similar } \\
\text { patterns. }\end{array}$ & $\begin{array}{l}\text { CPx in lherzolites are enriched in } \\
\text { LILE, HREE and depleted in HFSE, } \\
\text { LREE. Type I lherzolite from central } \\
\text { Oman ophiolite is relatively more } \\
\text { enriched than rest of the lherzolites } \\
\text { of other study areas of Oman } \\
\text { ophiolite. CPx in Harzburgite shows } \\
\text { lower abundance of trace element than } \\
\text { Lherzolite. Type I lherzolite from } \\
\text { northern Oman ophiolite shows } \\
\text { flat to spoon shaped REE patterns } \\
\text { typical signature of depleted melt } \\
\text { impregnation }\end{array}$ & $\begin{array}{l}\text { CPx in wehrlite has depleted } \\
\text { LREE and relatively flat to depleted } \\
\text { HREE pattern. } \\
\text { CPxs in wehrlite are LILE enriched } \\
\text { and they have Eu negative and Sr } \\
\text { positive anomalies }\end{array}$ \\
\hline
\end{tabular}

peridotite composition, similar to Josephine lherzolites. Ghosh et al. (2014) suggested that the clinopyroxenitewehrlite association was formed due to variable degree of mixing between extremely $\mathrm{Cpx}$ saturated melt generated by melt-mantle interaction and fresh magma increments. Wehrlite represents the residue left after the formation of clinopyroxenite. Hydrous melt impregnation and transformation of dunite to olivine rich troctolite was identified (Ghosh et al., 2014). Here, we suggested this phenomenon as clear indication of melt refertilisation.

\section{Concluding Remarks}

Ophiolitic peridotites are mainly composed of lherzolite, harzburgite and sometime wehrlite. Lherzolite represents fertile mantle whereas, 
harzburgite represents the mantle residue after melting of fertile mantle and are depleted in nature. Higher the melting degree, the more depleted peridotite will be. Andaman wehrlite represents the mantle transition zone rock and a melting residue. The influence of fluid percolation in fore arc peridotites, especially those formed in SSZ, are quite prominent. Melt percolation might results in refertilisation of peridotites. The REE and trace element patterns of secondary Cpx depend on the nature of percolating melt which can be either depleted or enriched. Oman ophiolite represents a complex polygenetic origin and Andaman ophiolite too have controversial origin (SSZ?) belonging to the same orogenic system, whereas Josephine ophiolite is part of the Caledonian orogeny, representing a clear influence of SSZ. However, Andaman peridotites are comparatively least studied so far and more discoveries are needed to unfold, in future. In this review, we

\section{References}

Alabaster T, Pearce J A and Malpas J (1982) The volcanic stratigraphy and petrogenesis of the Oman ophiolite complex Contrib Mineral Petrol 81 168-183 doi:10.1007/ BF00371294

Arai S (1994a) Characterization of spinel peridotites by olivinespinel compositional relationships: review and interpretation Chem Geol 113 191-204

Arai S (1994b) Compositional variation of olivine-chromian spinel in Mg-rich magmas as a guide to their residual spinel peridotites J Vol Geotherm Res 59 279-293

Arai S, Kadoshima K and Morishita T (2006) Widespread arcrelated melting in the mantle section of the northern Oman ophiolite as inferred from detrital chromianspinels Geol Soc London 163 869-879

Batanova V G, Suhr G and Sobolev A V (1998) Origin of geochemical heterogeneity in the mantle peridotites from the Bay of Islands ophiolite, Newfoundland, Canada: Ion probe study of clinopyroxenes Geochim Cosmochim Acta 62 853-866 doi: 10.1016/s00167037(97)00384-0

Benn K, Nicolas A and Reuber I (1988) Mantle-crust transition zone and origin of wehrlitic magmas: evidence from the Oman ophiolite Tectonophys 15 175-85

Boudier F and Nicolas A (1995) Nature of the Moho transition zone in the Oman ophiolite J Petrol 36 777-796

Boudier F, Ceuleneer G and Nicolas A(1988) Shear zones, thrusts and related magmatism in the Oman ophiolite: initiation of have summarised some of the possible characteristics of refertilised peridotite below which will help in identification of peridotites bearing SSZ influence.

i) The rocks will have high $\mathrm{Cr} \#$ in spinel and high to moderate $\mathrm{Mg} \#$ in olivine.

ii) The rocks will have secondary $\mathrm{Cpx}$ along grain boundaries of other minerals (mainly along orthopyroxene) or within interstices.

iii) LILE will be enriched whereas REE will be comparatively depleted.

iv) Higher the melting degree the depleted in nature it would be.

v) Majority of depleted peridotite (mostly Cpx poor harzburgite) forms in SSZ setting under the influence of slab derived melt/fluid.

thrusting on an oceanic ridge Tectonophysics 151 275-296

Dick H J B and Natland J H (1996) Late-stage melt evolution and transport in the shallow mantle beneath the East Pacific Rise. In: Mével C, Gillis K M, Allan J F and Meyer P S (Eds.) Proceedings of the Ocean Drilling Program, Scientific Results 147 College Station, TX, pp. 103-134

Dick H J B (1976) Origin and emplacement of the Josephine peridotite of southwestern Oregon. Dissertation, Yale University

Dilek Y, Furnes H and Shallo M (2008) Geochemistry of the Jurassic Mirdita Ophiolite

(Albania) and the MORB to SSZ evolution of a marginal basin oceanic crust Lithos 100 174-209

Gaetani G A and Grove T L (1998) The influence of water on melting of mantle peridotite Contrib Mineral Petrol 131 323-346

Ghosh B, Morishita T and Bhatta K (2013) Significance of chromianspinels from the mantle sequence of the Andaman ophiolite, India: Paleogeodynamic implications Lithos 164$16786-96$

Ghosh B, Morishita T, Sen Gupta B, Tamura A, Arai S and Bandyopadhyay D (2014) Moho transition zone in the Cretaceous Andaman ophiolite, India: A passage from the mantle to the crust Lithos 198-199 117-128

Harper G D (1984) The Josephine ophiolite, Northwestern California Geol Soc Am Bull 95 1009-1026

Hellebrand E, Snow J E, Hoppe P and Hofmann A W (2002) 
Garnet-field melting and late-stage refertilization in 'residual' abyssal peridotites from the Central Indian Ridge J Petrol 43 2305-2338 doi:10.1093/petrology/43.12.2305

Ishii T, Robinson P T, Maekawa H and Fiske R (1992) Petrological studies of peridotites from diapiric serpentinite seamounts in the Izu-Ogasawara-Mariana forearc, LEG125 In: Fryer P, Pearce J A and Stokking L B (Eds.), Proceedings of the Ocean Drilling Program: Scientific Results: Ocean Drilling Program 125 445-485

Jean M M, Shervais J W, Choi S H and Mukasa S B (2010) Melt extraction and melt refertilization in mantle peridotite of the coast range ophiolite: An LA-ICP-MS study Contrib Mineral Petrol 159 113-136 doi: 10.1007/s00410-0090419-0

Johnson K T M and Dick H J B (1992) Open system melting and temporal and spatial variation of peridotite and basalt at the Atlantis II fracture zone J Geophys Res 97 9219-9241

Johnson K T M, Dick H J B and Shimizu N (1990) Melting in the oceanic upper mantle; an ion microprobe study of diopsides in abyssal peridotites $J$ Geophys Res 95 2661-2678

Kelemen P B, Rilling J L, Parmentier E M, Mehl L and Hacker B $R$ (2003) Thermal structure due to solid-state flow in the mantle wedge beneath arcs. Inside the subduction factory, AGU, Washington 138 293-311

Khedr M Z, Arai S, Python M and Tamura A (2014) Chemical variations of abyssal peridotites in the central Oman ophiolite: Evidence of oceanic mantle heterogeneity Gondwana Res 25 1242-1262

Koga K T, Kelemen P B and Shimizu N (2001) Petrogenesis of the crust mantle transition zone and the origin of lower crustal wehrlite in the Oman ophiolite Geochem Geophys Geosyst 2 2000GC000132

Le Roux V, Bodinier J L, Tommasi A, Alard O, Dautria J M, Vauchez A and Riches A J V (2007) The lherz spinel lherzolite: refertilised rather than pristine mantle Earth Planet Sci Lett 259 599-612 doi:10.1016/jeps1.2007.05.026

LeMe'e L, Girardeau J and Monnier C (2004) Mantle segmentation along the Oman ophiolite fossil mid-ocean ridge Nature 432 167-172

Lippard S J, Shelton A W and Gass I G (1986) The ophiolite of northern Oman Geological Society Memoir 11 Blackwell, Oxford 178

McDonough W F, Sun S S, Ringwood A E, Jagoutz E and Hofmann A W (1992) K, Rb and Cs in the Earth and Moon and the evolution of the Earth's mantle Geochimica et Cosmochimica Acta 56 1001-1012

Monnier C, Girardeau J, Le Me'e L and Polve' M (2006) Alongridge petrological segmentation of the mantle in the Oman ophiolite Geochem Geophys Geosyst 711008 doi: 10.1029/ 2006GC001320

Muntener O, Pettke T, Desmurs L, Meier M and Schaltegger U (2004) Refertilization of mantle peridotite in embryonic ocean basins: Trace element and Nd isotopic evidence and implications for crust-mantle relationships Earth Planet Sci Lett 221 293-308 doi: 10.1016/s0012-821x(04)000731

Nicolas A, Boudier F, Ildefonse B and Ball E (2000) Accretion of Oman and United Arab Emirates ophiolite-discussion of a new structural map Marine Geophys Res 21 147-179

Nicolas A (1989) Structure of Ophiolites and Dynamics of Oceanic Lithosphere. Kluwer, Dordrecht

Niu Y (2004) Bulk-rock major and trace element compositions of abyssal peridotites: Implications for mantle melting, melt extraction and post-melting processes beneath mid-ocean ridges $J$ Petrol 45 2423-2458

Pal T (2011) Petrology and Geochemistry of the Andaman Ophiolite: Melt-rock interaction in a suprasubduction zone setting J Geol Soc London 168 1031-1045

Parkinson I J, Pearce J A, Thirwall M F, Johnson K T M and Ingram G (1992) Trace element geochemistry of peridotites from the Izu-Bonin-Mariana forearc, Leg 125. In: Fryer P, Pearce JA, Stokking LB (eds) Proceedings of the ODP Sci Results 125 . Ocean Drilling Program, College Station, Texas, 487-506

Parkinson I J and Pearce J A (1998) Peridotites from the IzuBonin-Mariana forearc (ODP leg 125): evidence for mantle melting and melt-mantle interaction in a supra-subduction zone setting J Petrol 39 1577-1618 doi:10.1093/petrology/ 39.9.1577

Pearce J A, Barker P F, Edwards S J, Parkinson I J and Leat P T (2000) Geochemistry and tectonic significance of peridotites from the south sandwich arc-basin system, South Atlantic Contrib Mineral Petrol 139 36-53

Pedersen R B, Searle M P, Carter A and Bandopadhyay P C (2010) U-Pb zircon age of the Andaman ophiolite: implications for the beginning of subduction beneath the Andaman-Sumatra arc Journal Geological Society London $1671105-1112$

Rampone E, Hofmann A W, Piccardo G B, Vannucci R, Bottazzi $P$ and Ottolini L (1996) Trace element and isotope geochemistry of depleted peridotites from a N-MORB type ophiolite (Internal Liguride, N-Italy) Contrib Mineral Petrol 123 61-76

Rampone E, Piccardo G B, Vannucci R and Bottazzi P (1997) Chemistry and origin of trapped melts in ophiolitic peridotites Geochim Cosmochim Acta 61 4557-4569 
Ray K K, Sengupta S and Van Den Hul H J (1988) Chemical characters of volcanic rocks of Andaman ophiolite, India $J$ Geol Soc 145 393-400

Roux Le V, Dick H J B and Shimizu N (2014) Tracking flux melting and melt percolation in supra-subduction peridotites, Josephine ophiolite, USA Contrib Mineral Petrol 1681064

Saleeby J B, Harper G D, Snoke A W and Sharp W D (1982) Time relations and structural-stratigraphic patterns in ophiolite accretion, west central Klamath Mountains, California J Geophys Res 87 3831-3848

Salters V J M and Stracke A (2004) Composition of the depleted mantle Geochem Geophys Geosyst 55

Sarma D S, Jafri S H, Fletcher I R and McNaughton N J (2010) Constraints on the tectonicsetting of the Andaman ophiolites, Bay of Bengal, India, from SHRIMP $\mathrm{U}-\mathrm{Pb}$ zircon geochronology of plagiogranite J of Geol 118 691697

Srivastava R K, Chandra R and Shastry A (2004) High-Ti type N-MORB parentage of basalts from the south Andaman ophiolite suite, India J of Earth System Sc 113 605-618

Suhr G, Seck H A, Shimizu N, Günther D and Jenner G (1998) Infiltration of refractory melts into the lowermost oceanic crust: evidence from dunite and gabbro-hosted clinopyroxenes in the Bay of Islands Ophiolite Contrib Mineral Petrol 131 136-154

Sun S and McDonoughWF (1989) Chemical and isotopic systematics of oceanic basalts: Implications for mantle composition processes, In: Saunders A D and Norry M J (eds) Magmatism in the Ocean Basins, Geological Society, London, Special Publications 42 p. 313-345

Takazawa E, Okayasu T and Satoh K (2003) Geochemistry and origin of the basal lherzolites from the northern Oman ophiolite (northern Fizh block) Geochem Geophys Geosyst 4 1-31 1021 doi: 10.1029/2001GC000232

Tamura A and Arai S (2006) Harzburgite-dunite-orthopyroxenite suite as a record of supra-subduction zone setting for the Oman ophiolite mantle Lithos 90 43-56

Vernie'res J, Godard M and Bodinier J L (1997) A plate model for the simulation of trace element fractionation during partial melting and magma transport in the Earth's upper mantle J Geophys Res 102 24771-24784

Warren J M (2016) Global variations in abyssal peridotite compositions Lithos 248-251 193-219 http://dx.doi.org/ 10.1016/j.lithos.2015.12.023

Whattam S A and Stern R J (2011) The 'subduction initiation rule': a key for linking ophiolites, intra-oceanic fore arcs, and subduction initiation Contrib Mineral Petrol 162 10311045

Widom E, Kepezhinskas P and Defant M (2003) The nature of metasomatism in the sub-arc mantle wedge: evidence from Re-Os isotopes in Kamchatka peridotite xenoliths Chem Geol 196 283-306

Workman R K and Hart S R (2005) Major and trace element composition of the depleted MORB mantle (DMM) Earth Planet Sci Lett 231 53-72 doi:10.1016/j.epsl.2004.12.005. 